\title{
病名用語の標準化と臨床医学オントロジー の開発
}

\section{Standardization of disease names and development of an advanced clinical ontology}

\author{
大江 和彦 ${ }^{1}$
}

\section{OHE Kazuhiko ${ }^{1}$}

1 東京大学大学院医学系研究科医療情報経済学分野（干113-8655 東京都文京区本郷7-3-1東大病院管理研究棟4F） Tel : 03-5800-6427

1 Department of Medical Informatics and Economics, Graduate School of Medicine, The University of Tokyo (Department of Planning, Information and Management, University of Tokyo Hospital 4F 7-3-1 Hongo Bunkyo-ku Tokyo, 113-8655)

電子カルテの導入が進みつつあり, 診療記録が電子化されてきた。診療記録は診療にだけ使用されるのではなく医学上 の新しい知見を得るための重要な情報の蓄積である。これを計算機処理により最大限活用するには, 電子力ルテで記 録される病名情報の標準化が重要であり，そのために筆者らは2002年より標準病名マスターを開発し提供してきた。 標準病名マスターでは, 疾患概念ごとに病名用語が標準化されデータベースとなっているが, その意味的な処理を可 能とするため, 疾患の概念定義を計算機上で記述した臨床医学オントロジーを開発している。臨床医学オントロジー では，疾患を注目病態とそれをとりまく患者状態の連鎖として記述し，多様な患者状態を表現できるようにしている。 本稿ではその考え方の概要を解説し，今後の発展性を論じる。

キーワード

オントロジー, 病名, 電子カルテ, 臨床研究, 医学用語集

1. 診療記録の目的と役割

電子カルテシステムの導入率は, 全体ではまだ 10\%弱であるが，大きな病院では30\%以上に導入 されている。医療では, 診察や検査により患者の状 態が情報として収集され，それを解䣋して診断を下 し, 治療を行う。そしてこの一連の過程を, 診療録, いわゆるカルテとして記録することが法的に義務づ
けられている。医療行為の多くは患者の身体になん らかの影響を与えるものであり, 状況によっては患 者に害を及ぼすものである。例えばX線検査は常に 少量の被爆を患者に強いるし, 医薬品の投与では化 学物質による身体へのなんらかの影響を与えること は必然である。医療は, そのデメリットに比して医 学的なメリットがあると考えられる場合にのみ許容 されている行為であるから，実施された医療行為の 
医学的正当性を第三者が検証できるようにしておか なくてはならない。法で診療記録が義務づけられて いる最大の理由はそこにある。また，実施された医 療に対して保険診療費請求を医療機関が行う場合に は，その請求が実施された医療を適正に反映したも のであるかを第三者が検証できるようにするために 一定の記載ルールがあり, それに従った記録が求め られている。

一方, 法的な観点とは別に, 診療の場での現実的 な必要性として，これまでの患者の状態はどうで あったか, 前回どのような診療をしたか, などの情 報を医療者が把握するために診療記録を残し，参照 する。医師が普段, 診療のためにカルテを書いてい るのはほとんどこの目的のためであり，法的な観点 はあまり日常的に意識しないことが多い。そのため, 医療者自身が診療に必要だと感じることは記録され ているが，第三者が後日医療を検証するために必要 となることは記録されていないといったことが往々 にして発生する。

さらにこうして記録され保管されている診療記録 を，例えば同じ病気で同じ治療をした患者のものだ けを過去にさかのぼって調べ，治療効果があった患 者の割合を調査したり, 治療後の副作用の内容と頻 度を分析したりするといつた研究を行うことがあ る。こうした研究はその手法や目的の違いによって, 臨床研究, 疫学研究などとさまざまに呼ばれている が，いずれにせよこうした研究では，診療記録を分 析することから新たな医学的知見を得て医療を発展 させる原データとして, 診療記録は非常に重要であ る。

整理すると，診療記録には，(1)法的根拠を残すた めの後日検証目的の記録, (2)診療に必要という現実 的かつ即時利用目的での記録, (3)医学研究のための 後日利用目的の記録, の3つの異なる目的がある。 日常診療では(2)の目的を優先して記録されがちであ り, 患者を別の医療機関に紹介する場合や複数の医 療機関同士で連携して診療にあたる場合にも，この
目的での情報のやりとりがなされ，患者にとっても 重要である。

しかし, 医療の発展という視点では(3)大変重要 である。従って, 電子カルテにおける重要な課題 は, 第一には, 日常診療の記録において, (3)の目的 での利用をするために必要な情報をいかに容易に記 録できる機能を実現するか，第二には，日常診療記 録からいかに(3)の目的での利用を効率よくできるよ うにするか, である。その解決のためには, 診療記 録で記述される臨床医学用語をできるかぎり標準化 し，それを日常診療でできるかぎり自然に使えるよ うにする技術開発が必須である。また, 診療記録を 解析し, 記述されている臨床医学的な出来事の同定 や，その時間的前後関係や因果関係記述の分析がコ ンピューター処理できるようにするには, 少なくと も記述されている臨床医学記述の意味的な処理が必 要であり, そのためには臨床医学用語の意味, すな わち定義を計算機処理可能な形で記述した知識が必 要である。

\section{2. 病名の標準化の必要性}

病名は, 患者の正常ではない状態を原因, 症状, 成り立ち, 重症程度などさまざまな視点から分類し て記述したものであり，患者状態を端的に把握する 上で最も重要な情報を提供する。同時に病名は診療 の根拠を示す情報としても位置づけられ，レセプト と呼ばれる診療費請求書と診療記録との両方に記載 が義務づけられている。当然ながら医師同士で情報 が共有できるようにするために，患者状態は一定の 用語すなわち病名で表現される。

しかし, どの程度詳細に患者状態を記述するかに ついては自由度が高く, 必要性によるので, 肝炎, ウイルス性肝炎, B型ウイルス性肝炎, 急性B型ウイ ルス性肝炎, などと伝えたい詳細程度 (情報粒度) にあわせてさまざまな用語で記述される。またある 患者状態の記述したい視点が病気の原因であればB 
型ウイルス性肝炎, 重症程度の視点であれば激症肝 炎, 両方であればB型激症肝炎, というように記述 が多様化する。またこの例のように多くの病名は複 数の性質を表す用語の複合語として構成されている が，その結合順序は臨床医学で慣用的に使いながら 決められてきたものが多く, 記述する人によって, 急性B型肝炎，B型急性肝炎のようにブレがあり，ど ちらも流通している。さらに，風邪はいろいろなウ イルスにより起こる上気道の急性感染症で, 原因ウ イルス名を区別して病名を記述すれば，エコーウイ ルス感染症, ライノウイルス感染症, などと記述し うるが，どれであっても治療方法も経過もほとんど 同じなので臨床医学上は区別する必要があまりない ため, 急性上気道感染症と包括的に記述することも 多い。

一方で，まったく同じ状態を表現する病名であっ ても，社会では痴呆を認知症と置き換えてきたよう に，病名が一般社会で使用されるため社会的な事情 により表記が変更されることもある。また，表記上 の摇れとして, 部分的に漢字をひらがなで表記する かどうか，外国人名を原語読みとするか英語読みと するか, 異字体漢字のどちらを使うか, などの表記 統一ができていない点もある。

こうしたさまざまな理由で, 患者状態を表現する 病名は, 同じ患者状態であっても多様な記述が可能 であるが，病名情報を電子カルテなどに記録し，計 算機処理する上では，少なくとも詳細度や視点が同 じである病名概念は同じ文字列で記述されるよう標 準化し，それぞれにコードを割り当てて計算機処理 が効率よく行えるようにすることが必須である。

\section{3. 標準病名マスターの開発}

標準病名マスターの開発は, レセプトを受領し点 検等を一括して実施する機関である社会保険診療報 酬支払基金，種々の医療用標準化マスターを開発・ 提供している (財) 医療情報システム開発センター
(MEDIS-DC) により厚生労働省のサポートのもとに 2000年より行われ，2002年に標準病名マスターと してリリースされるようになった1)。筆者はこの開 発編纂作業およびその後の年4回の改訂作業を, 担 当する委員会の委員長としてとりまとめている。前 述したように表現したい病名の詳細度は多様性が高 く, 新しい疾患概念や発見が絶え間なく続く臨床医 学領域では新たな病名の追加が常に必要で, 今後も 継続したメンテナンス作業が必要である。

標準病名マスターは, ある視点, ある詳細度で1 疾患概念に対して1見出し語（リードターム）を標 準病名表記として割り当て, それに対して病名交換 用コードと呼ばれる4桁の一意の英数字コードを割 り当てており, これは概念コードの性格を持つコー ドである。このコードには意味がなくランダム発生 されたものである。また痴呆症と認知症のように概 念は同一であるが表記が変更になるものや, 完全に 同義語であるが臨床上長く両方が区別されずに使わ れてきたものなどがあり，これらを異なる表記と して管理するために, 表記ごとに異なる病名管理 番号（表記番号）が割り当てられている。その他， 統計処理や診療費請求に必要となる国際保健機関 (WHO) の国際疾病分類コードであるICD10分類コー ドが割り当てられている。これらをひとつの表にし たものが病名基本テーブルであり, 約22,000語を収 載している。表のサンプルを表1に示す。

病名基本テーブルの各エントリーに対して, 表記 の摇れ, 歴史的あるいは慣用的に使用されてきた表 記などがまとめられた索引テーブルが作成されてお り, 両テーブルの対応レコードが病名交換用コード をキーとして連結されている。索引テーブルの収載 表記数は約88,000である。病名基本テーブルでは, ある疾患概念に対してどの表記を標準表記として採 用するかがポイントとなる。まったく同じ疾患概念 であっても異なる診療科の学会で別の病名を使って きたケースなどがあるが，どちらか一方に統一する ことは全国の診療医がそれに従うまで時間がかかる 
表1 標準病名マスターの病名基本テーブル（抜粋）

\begin{tabular}{|c|c|c|c|c|c|}
\hline $\begin{array}{c}\text { 病名管理 } \\
\text { 番号 }\end{array}$ & 病名表記 & 病名表記カナ & $\begin{array}{l}\text { 病名交換 } \\
\text { 用コード }\end{array}$ & ICD 10 & $\begin{array}{c}\text { レセプト } \\
\text { 電算コード }\end{array}$ \\
\hline 20051086 & アレルギー性肉芽腫性血管炎 & アレルギーセイニクゲシュセイケッカンエン & JV1D & M301 & 4460001 \\
\hline 20069105 & 多発性血管炎 & タハツセイケッカンエン & KSOV & M319 & 4460017 \\
\hline 2007579 & 閉塞性血栓血管淡 & 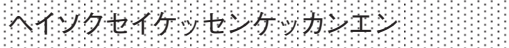 & NAC9 & 1731 & 4431010 \\
\hline 20052559 & $1-y+-$ 病 & $1+t+\emptyset$ & NAC9 & 1731 & 4431001 \\
\hline 20051072 & アレルギー性血管炎 & アレルギーセイケッカンエン & PG2J & $\mathrm{D} 690$ & 8830390 \\
\hline
\end{tabular}

上，もともとどちらかに統一することに理論的な根 拠があるわけではないため, 一方には受け入れられ ないことが多い。こうした問題を調整するために日 本の主要な医学関係学会が加入する日本医学会には 用語管理委員会があり，ここで学会間の調整を行 い, 可能なかぎり用語の統一を行った辞書として医 学用語辞典が出版されている2)。ちなみに冊子体購 入者はオンラインの最新版検索が利用できる3)。標 準病名マスターでは原則として日本医学会が統一し た用語を標準的な見出し語として病名基本テーブル に採用することとしている。しかし，どうしても臨 床の場で2つの病名が使われ続けている現状がある 場合には, 臨床の場での使用状況がどちらかにほぼ 統一されるまでの間, 当面は両方の使用を可能とす ることも必要で, そのようなケースのために病名基 本テーブルでは標準病名表記に対して互換語という カテゴリーの語の存在を一部で認めている。表1で は網掛けの2つの病名「閉塞性血栓血管炎」と「バー ジャー病」には同一の交換コードが割り当てられて おり, 前者が標準表記, 後者が互換語となっている。 図1でもその状況が確認できる。

標準病名マスターが開発されても, 臨床の場にお いて電子カルテを使って病名を記録する場合に使用 されなければ，意味がない。幸い，標準病名マス ターの見出し語は診療報酬請求書（レセプト）に原 則として記載することが厚労省通知により要求され
ており，レセプトはコンピューターにより作成され るものが大部分であるため, 多くのレセプト作成コ ンピューターシステムに標準病名マスターが搭載さ れ，そこから病名を選んで登録するようになってい ることが多い。また電子カルテシステムも同様に, 標準病名マスターまたはそのサブセットを搭載して 病名を選択させるようにしているシステムが多いた め, 普及が進んでいる。ただ, 医師や医療事務者が システムで入力したいと思った病名をマスターから 検索するための検索機能が貧弱なシステムも少なか らずある。前述した索引語テーブルを同義語や表記 摇れデータとして利用して検索する機能を装備すれ ばかなり高確率で登録したい病名を検索することが できるが，このような機能を十分に持たないシステ ムもあるようで，使用に関するノウ八ウの普及が鍵 である。

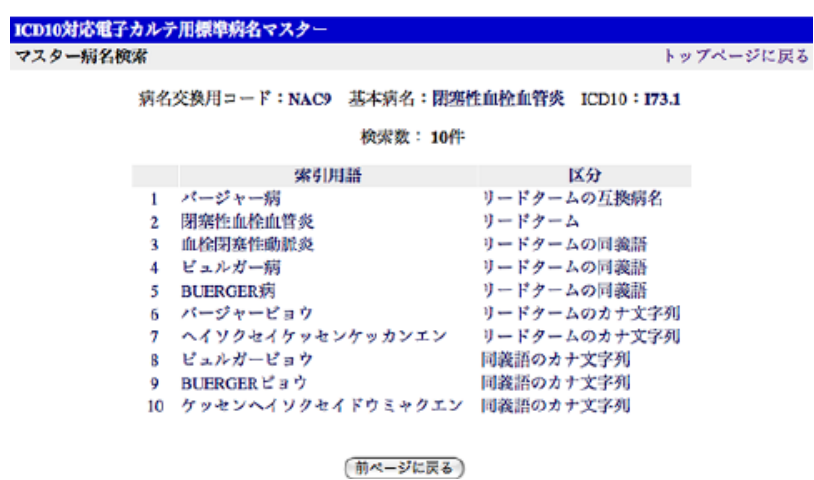

図1 基本病名（リードターム）と索引用語との関係の例 
なお標準病名マスターを効率よく検索するソフト ウェアとして, 筆者らは「病名くん」というソフト ウェアをフリーで提供しているので関心のある方は 利用してみてほしい4)。

\section{4. 病名情報の意味処理に向けたオントロ ジー開発}

これまで述べてきたように，標準病名マスターは 臨床の場で日常に使用される病名を，1疾患概念に1 標準用語として整理した表であるが，各概念間に意 味関係を持たない。しかし，実際に使用する場合に は, 文字列による検索以外に, 疾患体系から樹構造 メ二ューをたどって病名を見つける必要性は当然存 在し，これを実現するためには，シソーラスのよう な上位一下位ツリーを作成できるように，意味の上 下関係情報を標準病名の各エントリーに付加するこ とが必要である。実際，標準病名マスターでもその リリースの初期の段階では, ある程度の上位下位情 報を付与した臨床病名階層メ二ューテーブルを運用 上の補助テーブルとして開発し提供はしているが, その後メンテナンスは行っていない。上位下位情報 を継続的に付与することの大きな問題は, 中間分類 として何をどの順で配置するかについて臨床医学上 のコンセンサスが得られず，利用目的によりどのよ うな階層整理が適当であるかが多様に変化し，ひと とおりの上位下位分類を定義するだけでは使い物に ならないことである。使える上位下位ツリーを形成 するには，利用目的や視点によってツリー構造がダ イナミックに変容可能な情報構造を持つ必要があ る。また，ある親分類の下に配置される複数の病名 概念同士が，親分類から見て互いに排他的な意味を もつ兄弟概念でもなく，しかし両者に意味の上下関 係があるわけでもないというケースは非常に多く， こうした病名同士を単にツリー状に構造化しても臨 床上有用な使い方はできない。

筆者は，この問題を解決するひとつの手法とし
て, 個々の基本となる疾患概念の定義を計算機処理 可能な形で記述し， ある疾患と他の疾患との意味的 な関係はそれぞれの定義を比較することで必要時に 導出できるようにしたいと考えている。そしてその ために必要となる「疾患概念定義の計算機処理可能 な形での記述」を, 大阪大学産業科学研究所の溝口 研究室が開発したオントロジー構築ツールである法 造 (http://www.hozo.jp) を使用してオントロジー開 発を行うことにより実現することを目指し，溝口ら とともに2007年度から研究開発を続けている。以 下では，このオントロジー構築の考え方について解 説する。

\section{5. 疾患オントロジーの考え方}

病名によって表現されている疾患概念とは何か, を十分に議論することから始める必要がある。身体 心身になんらかの原因で通常とは異なる状態が発生 し, それが次々と別の状態を引き起こし，その一部 の結果として身体心身がいつもとは違う何かを自覚 したり，他覚されたり検査により異常な結果が出る ような状態を引き起こす。疾患とは，身体心身のな んらかの異常状態として定義でき, その疾患の必要 十分条件としての異常状態を記述することによって 記述できると当初は考え，その方針で開発を進めて いた時期があった。

例えば糖尿病の概念は「糖尿病は, インスリン作 用の不足による慢性高血糖を主徵とし, 種々の特徵 的な代謝異常を伴う疾患群である。その発症には遺 伝因子と環境因子がともに関与する。代謝異常の長 期間にわたる持続は特有の合併症を来たしやすく， 動脈硬化症をも促進する。代謝異常の程度によって, 無症状からケトアシドーシスや昏睡に至る幅広い病 態を示す」と日本糖尿病学会のホームページ5)に記 載されている。当初の方針はこうした記述の前半部 分を概念化するべく, 糖尿病の必要十分条件として, 「持続的高血糖がある異常状態」を記述し，派生す 


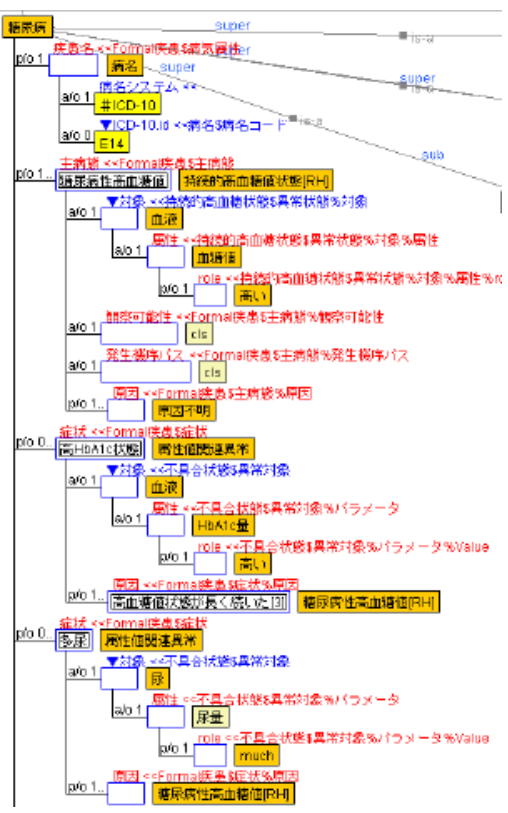

図2 糖尿病を, 持続的高血糖状態を必要十分条件として定義し, 高HbA1cなどの検査結果異常や多尿といった症状は起こりうる 状態として列挙したオントロジー（開発当初の方針）

る種々の症状や検査異常を起こりうる状態として記 述していた(図2)。

この記述方針では，例えば「治療中で良好に血糖 がコントロールできている糖尿病」は血糖が持続 的に高いという上位概念の性質を受け継がない点 で，単純に糖尿病のサブクラスと言えないこととな り，疾患とその治療状態との意味関係を的確に記述 できない。こうした問題を取り扱えるようにするた め, 議論を重ねた結果，疾患概念は，「その原因之 途中経過を含めた一連の状態変化の連鎖と，それに より引き起こされている1以上の結果状態との総体」 としてとらえるのが適当であるという立場を現在は とっている。糖尿病を例にすると, 糖尿病とは, 身 体の日常活動におけるインスリン機能の需要最大值 に対して，インスリン作用の供給可能な最大值が低 いという状態が，なんらかの原因により引き起こさ れており，その結果として，インスリン需給バラン スが崩れることがあれば血糖が上昇し，崩れていな ければ血糖が正常を保っていることもある状態であ り，それにより高血糖が持続する状態が起こればさ まざまな合併症が引き起しされうる状態として定義
される。こうすることにより,「インスリン注射に より需給バランスがとりあえず保たれ良好に血糖が コントロールでき, 結果として血糖が常時高いわけ ではないが，注射をやめれば高血糖が持続する」と いった糖尿病のコントロール状態も自然な形で記述 することができる。またこのように定義された糖尿 病に，特定の原因を追加記述することにより，特定 ではない原因により起こっているとして記述した概 念である糖尿病よりも, 意味的に特化している点で 糖尿病のサブクラス化することになる。例えばステ ロイド糖尿病といつた特定の薬剤により引き起こさ れるインスリン需給バランスが崩れた病的な状態も 糖尿病の下位概念として容易に記述できる。

前述した日本糖尿病学会ホームページにある糖尿 病の概念の後段部分「代謝異常の程度によって, 無 症状からケトアシドーシスや昏睡に至る幅広い病態 を示す」は疾患の定義を一般的に考える上で非常に 意味深い。糖尿病では, 高血糖が持続する結果とし て引き起こされうる種々の身体変化状態を総体とし てとらえていることになる。一方で, 糖尿病特有の 合併症という表現で記述されている個々の身体変化 は, すべての糖尿病患者で常にすべてが発生するわ けではなく, その重症程度, 経過の長さ, 治療の経 過などさまざまな要因によって, 見られるものもあ れば見られないものもある。また上記の記述には動 脈硬化のように糖尿病以外の原因により引き起こさ れる状態も含まれている。そこで，われわれは，前 述の疾患の定義で記述される状態がさらにその後に 連鎖的に引き起こす状態变化の広範な状態連鎖があ ることを想定し，それを対象疾患連鎖と呼ぶ。前出 ホームページでの定義の後段部分の記述は, この対 象疾患連鎖を表現していると考えられる。そして対 象疾患連鎖は必要に応じて計算機処理により形成で きることを前提とした上で, 疾患概念において必要 十分な部分連鎖だけを定義として記述したものが 個々の疾患概念の定義であると考えることとし，こ れを注目疾患連鎖と呼ぶことにしている。 
以上の考え方を図3に，糖尿病の例を図4に示す。 また，図5にこうして記述された糖尿病，।型糖尿病 (インスリン依存性糖尿病)，失明を伴った糖尿病の それぞれの記述と相互間の関係を示す。

\section{6. 海外における臨床医学オントロジー}

米国で開発されてきたSNOMED-CTは，実用レ ベルにある医学オントロジーの代表的なものであ る。デンマークに本部がある9か国からなるIHTSDO (International Health Terminology Standards Development Organization) という非営利国際機関が維持管理組

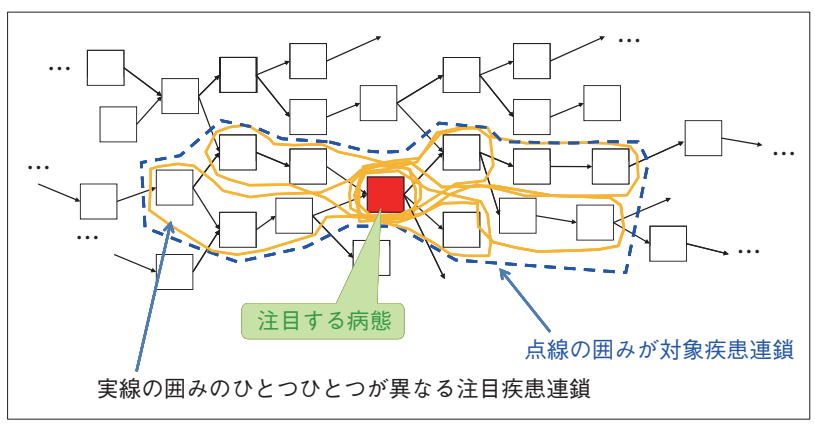

図3＼cjkstart疾患における病態の連鎖のとらえ方
織となっており, 維持業務は当初からの開発組 織である米国病理医学会CAP (College of American Pathologists) が受託している。SNOMED-CTは, 当初 は病理診断に使用する医学用語の記述法とコードを 意味的に体系化するために開発されてきたが，現在 では30万以上の医学概念が80万語近い用語により 記述され相互間に意味的な関係付けがなされてそ の種類は60種類近くに及ぶ，一種のオントロジー として利用できるデータベースに成長している。 SNOMED-CTはこうした開発の歴史から, 個々の医学 概念の意味を一定の形式で定義することから始まっ たわけではなく, これまでに収載されてきた膨大な

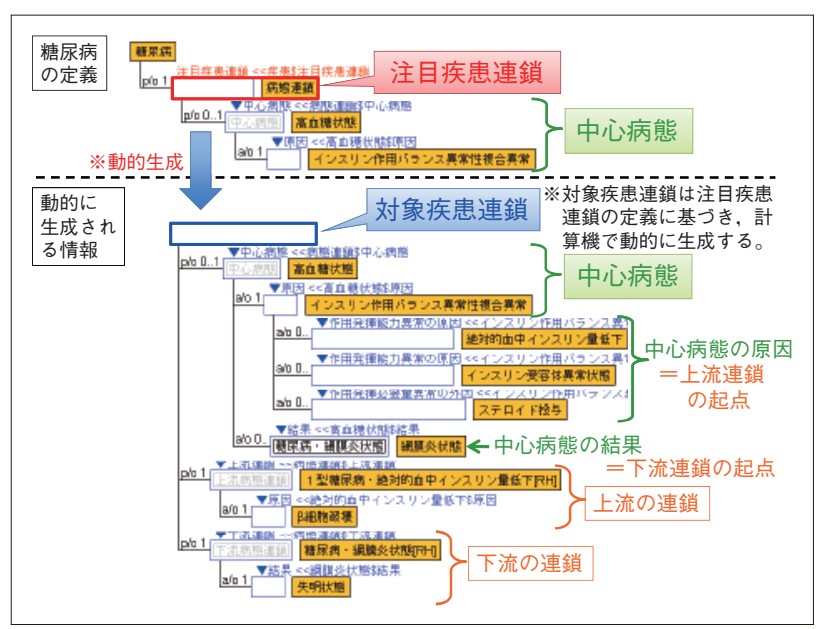

図4＼cjkstart糖尿病の記述例

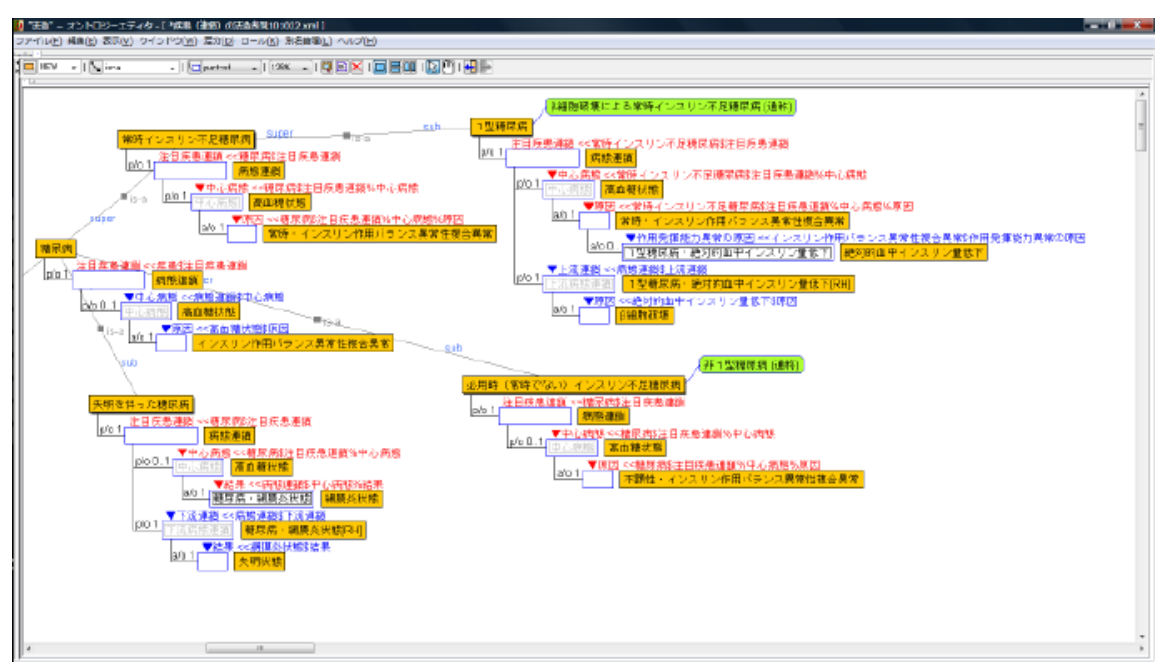

図5 オントロジー構築ツール「法造」による疾患オントロジー

（糖尿病，インスリン依存性糖尿病（Ｉ型糖尿病），失明を伴った糖尿病の関係の記述例） 
数の医学用語の間に意味的な関係付けをすることに よって結果的にオントロジーの性格を持つように なったものと筆者は見なしている。そのため, 疾患 とは何か, 検査所見亡は何か, といった視点で意味 を定義するための記述形式を決定し，それに従って 疾患や検査所見を他の医学概念により記述していく といつた筆者らが構築しつつあるオントロジーとは 異なり, SNOMED-CTは知識の記述形式に一定の原 則がないため計算機による推論や新しい意味関係の 生成といった高度な処理には使いづらいと考えてい る。しかし, 一方でその収載概念の多さや, 国際的 な維持管理体制, 英語圏での利用できる唯一といつ てよいリソースであることは, 英語での臨床情報を コーディングするという利用で大きな力を発揮する と予想される。従ってSNOMED-CTでコーディング された英語臨床情報をより高度に意味解析する目的 で，筆者らが構築中のオントロジーを活用できるよ うにすることを目指す必要があり，そのためには， 両者間でのコードマッピングが重要な作業となるだ ろう。なお, SNOMED-CTの詳細は本誌51巻4号に解 説されているのでそちらを参照いただきたい6)。

\section{7. 医療情報システムの知識基盤の構築と その活用に向けて}

臨床医学オントロジー研究開発プロジェクトは, 2007年度から厚生労働省の医療情報システムの知 識基盤開発研究事業の委託を受けて東京大学の筆者 ら, 大阪大学産業科学研究所溝口理一郎研究室グ ループが中心となり進行中である。本稿で取り上げ た注目疾患連鎖により定義されることが適切な疾患 以外にも, 外傷などの外因性傷病名, 症状群により
定義される症候群と呼ばれる一連の病名, またそれ らの疾患定義に現れる解剖学的な構造物のオントロ ジーについて記述を進めている7),8)。

当面の目標は, 標準病名マスターの基本病名テー ブルに収載されている傷病名のうち, 精神疾患関連 の傷病名や単に重症度や疾患の特定の病気段階だけ を表すために収載されている粒度の細かい傷病名を 除いた基本的と考えられる疾患についてオントロ ジーを構築することである。そしてこれをもとにし て, 前述したように, 標準病名マスターに臨床上の 複数の視点で意味の上下関係を自動的に生成する予 定である。こうした臨床医学オントロジーとその派 生データベースは, 冒頭に記載したような電子カル テを用いた日常診療において，診療目的だけでなく 臨床研究にも使える詳細度で診療を記録するために 必要亡なる高度なユーザーインターフェイスの実現 に貢献すると考えられる。

また，オントロジーの疾患連鎖や動的に生成され た意味の上下関係をナビゲーションして見せるツー ルを開発することにより, 複雑な臨床医学知識を特 定の視点で体系化, 構造化して見せることができれ ば, 知識ナビゲーション機能を持った医学教科書と して医学生や研修医などの教育にも役立つ可能性が ある。さらに症状や検査異常との関連の記述を深め ることにより, 診断支援システムなどにも発展させ ることができる。

このように臨床医学オントロジーは, 臨床医学知 識を扱う医療情報システムの基盤として活用できる 可能性を秘めており, 今後さらにその記述内容と力 バーする範囲を拡大するとともに，活用のためのソ フトウェア開発を進める予定である。 
1）財団法人医療情報システム開発センター.MEDIS標準マスター総合サイト.http://www.medis.or.jp/4_ hyojyun/medis-master/index.html, (参照2010-02-02).

2）日本医学会医学用語管理委員会編. 日本医学会医学用語辞典英和 第3版. 南山堂, 2007.

3）日本医学会. “日本医学会医学用語管理”。日本医学会. http://jams.med.or.jp/dic/mdic.html, (参照2010-0202).

4）標準病名マスター作業班ホームページ. http://www.dis.h.u-tokyo.ac.jp/, (参照2010-02-02).

5）日本糖尿病学会糖尿病診断基準検討委員会. “糖尿病診断基準 : 糖尿病の分類亡診断基準に関する委 員会報告”。 日本糖尿病学会. http://www.jds.or.jp/jds_or_jp0/modules/committee/index.php?id=20, (参照 2010-02-02).

6）柏木公一. 国際医療用語集SNOMED-CTの成立と概要，日本への影響. 情報管理. 2008, vol. 51, no. 4, p. 243-250.

7）国府裕子, 周俊, 古崎晃司, 今井健, 大江和彦, 溝口理一郎. “臨床医療オントロジーの構築に関する基 礎的な考察”。第22回人工知能学会全国大会, 2008. http://www.ai-gakkai.or.jp/jsai/conf/2008/program/ pdf/100099.pdf, (参照2010-02-02).

8) Riichiro Mizoguchi; Hiroko Kou; Jun Zhou; Kouji Kozaki; Ken Imai; Kazuhiko Ohe. "An Advanced Clinical Ontology". Proc. of International Conference on Biomedical Ontology (ICBO). Buffalo, NY, 2009-07-24/26, p. 119-122. http://precedings.nature.com/documents/3498/version/1, (accessed 2010-02-02).

\section{Author Abstract}

Electronic medical records have been adopted gradually in many hospitals and they are becoming invaluable information resources for evidence-based clinical medicine. Standardized disease names should be recorded in such electronic medical records for advanced analyses for clinical researches and the standard master of controlled terms was developed and released in 2002. In the master, only one disease name label for a disease concept is defined as the standard name and there are no semantic relationships among the concepts. Now the authors are developing an advanced clinical ontology based on the policy that diseases could be defined by a combination of a focused disordered condition and partial causal chain of related conditions including the focus. In this paper, the standard master and the advanced clinical ontology will be introduced.

\section{Key words}

ontology, disease name, electronic medical record, clinical research, medical terminology 